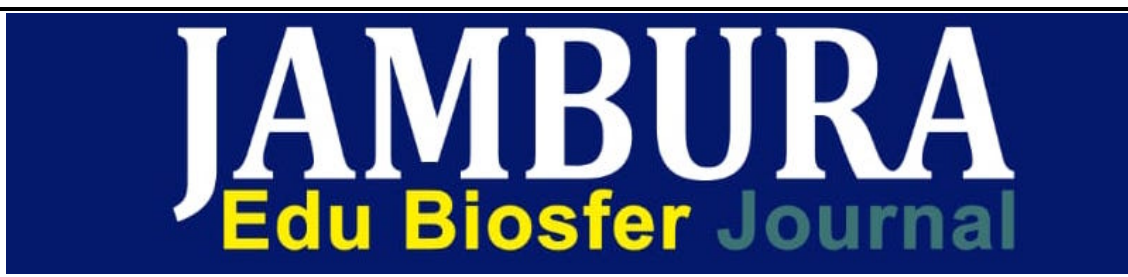

Journal homepage: http://ejurnal.ung.ac.id/index.php/edubiosfer

\title{
AKTIVITAS ENTOMOPATOGEN Serratia marcescens Bizio TERHADAP MORTALITAS LARVA KUMBANG KELAPA (Brontispalongissima) Gestro
}

\author{
Siti Ramla S Kahar ${ }^{\mathrm{a}}$, Ani M. Hasan ${ }^{\mathrm{a}}$, Chairunnisa J. Lamangantjo \\ Jurusan Biologi, Fakultas Matematika Ilmu Pengetahuna Alam, Universitas Negeri Gorontalo, J1. \\ Jenderal Sudirman, No. 06 Kota Gorontalo- 96128, Provinsi Gorontalo, Indonesia. \\ Sitiram355@gmail.com
}

\begin{abstract}
Entomopatogen merupakan salah satu agen hayati yang menginfeksi serangga serta dapat merusak sistem metabolisme tubuh serangga. Penelitian ini bertujuan untuk mengetahui aktivitas entomopatogen $S$. marcescens terhadap mortalitas larva kumbang kelapa (B. longissima) Gestro, dan waktu yang dibutuhkan untuk mencapai $\mathrm{LT}_{50}$. Metode yang digunakan adalah metode eksperimen dengan 6 perlakuan pemberian S.marcescens dengan volume bervariasi, terdiri dari A (akuades sebagai kontrol), B $(5 \mathrm{ml})$, C $(7,5 \mathrm{ml})$, D $(10 \mathrm{ml}), \mathrm{E}(12,5 \mathrm{ml})$, dan F $(15 \mathrm{ml})$ dengan 4 ulangan. Data dianalisis menggunakan uji ANAVA dan Probit $\mathrm{LT}_{50}$. Hasil penelitian menunjukkan bahwa volume S.marcescens berpengaruh terhadap mortalitas larva kumbang kelapa B. longissimiGestro. Mortalitas larva B. longissima tertinggi ditunjukkan oleh pemberian $12,5 \mathrm{ml} S$. marcescens yaitu sebesar $78 \%$, sedangkan $\mathrm{LT}_{50}$ yaitu 42,5 jam pada perlakuan $\mathrm{F}$. S.marcescens memiliki aktivitas entomopatogen pada larva kumbang kelapa (B. longissima) Gestro.
\end{abstract}

Kata Kunci: Entomopatogen, Serratia marcescens, Brontispa longissima, Mortalitas

Entomopathogen is one of the biological agents that infects the insects. It shows ability to damage the metabolic system in insects body. The objectives of the study were to determine the entomopathogenic activity of $S$. marcescens on mortality of coconut leaf beetles larvae (B. longissima) Gestro, and the time needed to reach $\mathrm{LT}_{50}$. The study use an experimental method with 6 treatments of varying S.marcescens volumes, consisting of A (distilled water as a control), B $(5 \mathrm{ml}), \mathrm{C}(7.5 \mathrm{ml}), \mathrm{D}(10 \mathrm{ml}), \mathrm{E}(12.5 \mathrm{ml})$, and $\mathrm{F}(15 \mathrm{ml})$ with 4 replications. The data were analyzed using ANOVA and Probit LT50 test. The results showed that the volume of $S$.marcescens had an effect on mortality of coconut leaf beetle $B$. longissimi larvae Gestro. The highest mortality of $B$. longissima larvae shows by treatment $12.5 \mathrm{ml}$ of $S$. marcescens about $78 \%$, while $\mathrm{LT}_{50}$ was 42.5 hours on $\mathrm{F}$ treatment. S.marcescens has entomopathogenic activity in coconut leaf beetles (B. longissima) Gestro larvae.

\section{Pendahuluan}

Tanaman kelapa merupakan komoditas perkebunan di Gorontalo. Tanaman tersebutbermanfaat di bidang ekonomi masyarakat, juga aspek sosial, budaya, pangan dan papan (Lumentut \& Indrawanto 2013). Namun demikian, terdapat permasalahan yang dihadapi petani kelapa adalah gangguan hama khususnya kumbang kelapa (B.longissima), sehingga menurunkan hasil produktivitas kelapa hingga 30\%-40\% (Alhadad dkk 2012).Kumbang kelapa B.longissima memiliki siklus hidup selama 52-60 hari yang diawali dari larva hingga mencapai fase imago (Lumentut et al.,2013). Lebih lanjut, Lumentut \& Indrawanto (2013) melaporkan bahwa bahwa fase imago merupakan fase aktif untuk menyerang tanaman kelapa. Sehingga untuk mencegah terjadinya serangan serta penyebaran B.longissima perlu diantisipasi dengan memotong siklus hidup B.longissima pada fase larva dengan memperkecil dampak negatif terhadap lingkungan.

Upaya pengendalian serangan hama dari kelompok serangga adalah penggunaan agen hayati entomopatogen (Widariyanto $\mathrm{dkk}, 2017$ ). Salah satu agen entomopatogen adalah bakteri jenis $S$. 
marcescens atau dikenal sebagai bakteri merah. Bakteri ini diketahui bersifat patogen terhadap $N$. lugens (Priyatno dkk, 2011) dan Periplenata americana (Rini dkk, 2016). Namun demikian, kajian tentang penggunaan S.marcescens sebagai entomopatogen pada kumbang kelapa B.longissima belum pernah dilaporkan. Oleh karena itu perlu dilakukan kajian terkait kemampuan patogenitas S.marcescens terhadap kumbang kelapa B.longissima.

Penggunaan bakteri entomopatogen S.marcescens sebagai entomopatogen untuk menekan populasi B.longissima merupakan langkah awal untuk penelitian selanjutnya. Hal ini disebabkan kajian yang terkait dengan penggunaan volume bakteri $S$. marcescens terhadap B.longissima pada fase larva belum dilaporkan. Untuk itu, pemanfaatan $S$. marcescensdiduga memberikan jawaban terkait patogenitasnya terhadap larva B.longissima. Berdasarkan uraian tersebut sehingga perlu kajian untuk mengetahui pengaruh volume S.marcescens terhadap mortalitas larva kumbang kelapa (B.longissima), dan untuk mengetahui waktu yang diperlukan $S$.marcescens mencapai $\mathrm{LT}_{50}$.

\section{Metodologi}

\subsection{WaktudanTempatPenelitian}

Penelitian ini dilaksanakan pada bulan Januari sampai dengan Februari 2019, di Laboratorium Biokimia, Fakultas Matematika dan Ilmu Pengetahuan Alam, Universitas Negeri Gorontalo.

\subsection{MetodedanPengumpulan Data}

Metode yang digunakan dalam penelitian ini yaitu metode eksperimen. Pengumpulan data yakni menghitung mortalitas larva $B$. longissima yang ditunjukkan dengan ciri-ciri mengalami perubahan warna, berbau busuk, tidak bergerak,dan berair(Salaki 2011).

\subsection{Alat dan Bahan}

Alat yang digunakan dalam penelitian ini antara lain; cawan petri, erlenmeyer, jarum ose, handsprayer, spektrofotometer, oven dan autoklaf. Bahan yang digunakan dalam penelitian ini diantaranya Nutrient agar (NA), Nutrient broth (NB); alkohol 75\%; larva B.longgissima, dan S. marcescens.

\subsection{Penyiapan kultur S.marcescens dan PengujianPetogenitasterhadap larva B.longgissima}

Penyiapan kultur S.marcescens -- Bakteri S.marcescensditumbuhkan pada $100 \mathrm{ml}$ medium NB pada suhu $30^{\circ} \mathrm{C}$ selama $24 \mathrm{jam}$. Pertumbuhan bakteri diamati secara spektrofotometri sampai mencapai kerapatan sel $10^{8} \mathrm{cfu} / \mathrm{ml}$ dan digunakan sebagai stok bakteri.Stok bakteri digunakan untuk penelitian selanjutnya dengan variasi perlakuan sebagai berikut: A. akuades sebagai control; B. $5 \mathrm{ml} ; \mathrm{C} .7,5 \mathrm{ml} ; 10 \mathrm{ml}$, D. $12,5 \mathrm{ml}$; dan E. $15 \mathrm{ml}$.

Pengujian patogenitas -- Pengujian patogenitas bakteri $S$. marcescens terhadap B. longissima mengacu pada Rini dkk (2016). Janur kelapa sebagai media tumbuh larva $B$. longissima dengan panjang $5 \mathrm{~cm}$ dan diletakkan pada setiap wadah plastik berdiameter $72 \mathrm{~cm}^{2}$. Larva $B$. longissima instar 3 sebanyak 10 individu dimasukkan ke dalam setiap wadah plastik yang telah berisikan janur kelapa. Selanjutnya disemprot dengan volume $S$. marcescens sesuai perlakuan yang telah ditetapkan dengan ulangan sebanyak 4 kali. Pengamatan mortalitas larva diamati setiap interval waktu 3 jam pada hari pertama, dilanjutkan setiap interval waktu 12 jam sampai 72 jam setelah aplikasi.

\subsection{Model Penelitian}

Model penelitian yakni menggunakan Rancangan Acak lengkap (RAL) dengan perlakuan ditentukan menggunakan rumus $(\mathrm{t}-1)(\mathrm{r}-1)=\geq 15$ didapatkan 6 perlakuan dan 4 kali ulangan. Perlakuan konsentrasi volume starter bakteriS. marcescens yang digunakan dalam penelitian ini yakni 0 $\mathrm{ml}, 5 \mathrm{ml}, 7,5 \mathrm{ml}, 10 \mathrm{ml}, 12,5 \mathrm{ml}$, dan $15 \mathrm{ml}$.

\subsection{Analisis Data}

Data persen mortalitas diuji statistik untuk melihat pengaruh volume S.marcescens terhadap mortalitas B.longissima. Nilai persen mortalitas dianalisis statistik menggunakan uji Fisher (F) dengan nilai signifikan pada taraf 5\%, kemudian dilanjutkan dengan uji lanjut Duncan untuk melihat perbedaan yang signifikan antar perlakuan dengan bantuan aplikasi SPSS 16. Data jumlah mortalitas larva B.longissima setiap jam setelah aplikasi $(3,6,9,12,24,36,48,60$ dan 72 jam) pada masing-masing 
perlakuan dianalisis menggunakan analisis probit untuk mengetahui nilai $\mathrm{LT}_{50}$ Nilai persen mortalitas didapatkan dari rumus sebagai berikut (Yus dkk, 2014):

$\%$ Mortalitas $=\left(\frac{\sum \text { serangga yang mati }}{\sum \text { serangga uji }}\right) \times 100 \%$

jika kontrol mengalami kematian lebih dari 20\% maka perlu dilakukan uji mortalitas terkoreksi dengan rumus:

$\mathrm{P}=\left(\frac{X-y}{X}\right) \times 100 \%$

dimana, $\mathrm{P}$ adalah presentasi kematian yang terkoreksi, $\mathrm{X}$ adalah presentasi B.longissima yang hidup pada kontrol dan y adalah presentasi B.longissima yang hidup pada perlakuan.

\section{Hasil dan Pembahasan}

\subsection{Pengaruh Aktivitas S.marcescens terhadap Nilai Presentase Mortalitas Larva B.longissima}

Nilai persen mortalitas merupakan presentase dari hasil pembagian antara nilai total larva yang mati pada setiap jam perlakuan dengan total larva uji. Hasil penelitian menunjukkan pada masingmasing perlakuan larva mengalami mortalitas pada 12 jsa (jam setelah aplikasi). Presentase nilai persen mortalitas larva B. longissima pada setiap perlakuan selama waktu pengamatan 72 jam disajikan pada Tabel 3.1.

Tabel 3.1.Presentase mortalitas larva B.longissima pada setiap perlakuan selama pengamatan

\begin{tabular}{ccccccc}
\hline \multirow{2}{*}{$\begin{array}{c}\text { Waktu } \\
(\mathrm{Jam})\end{array}$} & Jsa & \multicolumn{7}{c}{ Persen Mortalitas (\%) pada setiap Perlakuan } \\
\cline { 2 - 7 } & Kontrol & $5 \mathrm{ml}$ & $7,5 \mathrm{ml}$ & $10 \mathrm{ml}$ & $12,5 \mathrm{ml}$ & $15 \mathrm{ml}$ \\
\hline 3 & 0 & 0 & 0 & 0 & 0 & 0 \\
6 & 0 & 0 & 0 & 0 & 0 & 0 \\
9 & 0 & 0 & 0 & 0 & 0 & 0 \\
12 & 0 & 3 & 5 & 8 & 10 & 10 \\
24 & 0 & 5 & 13 & 15 & 18 & 18 \\
36 & 0 & 8 & 15 & 20 & 35 & 28 \\
48 & 0 & 15 & 30 & 28 & 50 & 50 \\
60 & 0 & 25 & 40 & 45 & 65 & 70 \\
72 & 0 & 40 & 50 & 63 & 78 & 93 \\
\hline
\end{tabular}

Tabel 3.1 menunjukkan nilai mortalitas tertinggi rata-rata terdapat pada waktu pengamatan 72 jam setelah aplikasi (jsa). Nilai persen mortalitas pada setiap perlakuan setelah aplikasi tertinggi yakni pada perlakuan $15 \mathrm{ml}$ yaitu $93 \%$ dan yang paling rendah pada perlakuan kontrol $0 \%$ kemudian nilai terendah kedua dan seterusnya diikuti oleh $5 \mathrm{ml} \mathrm{7,5} \mathrm{ml;} 10 \mathrm{ml}$; dan 12,5 ml berturut-turut adalah $40 \%, 50 \%$, $63 \%$, dan $78 \%$. Perlakuan kontrol selama waktu pengamatan berlangsung larva tidak mengalami mortalitas. Aktivitas mortalitas larva $B$. Longissimaterjadi pada waktu pengamatan 12 jsa sedangkan pada waktu pengamatan 9 jam pertama larva tidak mengalami mortalitas.

Pengaruh aktivitas bakteri $S$. marcescens terhadap mortalitas larva kumbang kelapa (B. longissima) berdasarkan analisis statistik One Way Anova dengan nilai signifikan pada taraf 5\% menunjukkan bahwa perlakuan volume S.marcescens berpengaruh terhadap persentase mortalitas larva B.longissima. Hasil analisis statistik uji $F$ menunjukkan nilai $F$ hitung 41.301 pada taraf signifikan 0,05 . Hal ini membuktikan bahwa terdapat pengaruh volume S.marcescens terhadap mortalitas larva B. longissima. Perlakuan volume $S$. marcescens mempengaruhi tingkat patogenitas bakteri. Yus dkk (2014) melaporkan bahwa perlakuan kerapatan sel bakteri entomopaogen mempengaruhi tingkat mortalitas larva uji.

Aktivitas patogenitas bakteri $S$. marcescensditandai dengan adanya mortalitas yang berlangsung secara bertahap. Pada satu jam setelah aplikasi (jsa), tubuh larva bergerak cepat dan menggulung. Selanjutnya, pengamatan 3 jsa, beberapa larva menjauhi daerah yang tergenang air yang berisi bakteri. Pengamatan 6 - 9 jsa, larva memiliki gerakan yang lambat dan kurang beraktivitas. Gerakan larva yang lambat diduga bakteri $S$. Marcescens sudah menginfeksi larva $B$. longissima sehingga terjadi penurunan 
aktivitas larva akibat paralisis. Bakteri membutuhkan waktu untuk menyesuaikan diri dengan lingkungan baru sehingga proses patogenitas bakteri belum terlihat secara langsung melainkan bertahap. Hal ini sesuai dengan pendapat Hidayat dkk (2006) bahwa bakteri membutuhkan penyesuaian diri dengan lingkungan baru hingga keadannya memungkinkan terjadinya pertumbuhan lebih lanjut.

Mortalitas larva $B$. longissima yang didapatkan dari setiap perlakuan menunjukkan, perlakuan kontrol terlihat larva tidak mengalami mortalitas sehingga larva yang berada pada perlakuan kontrol terus mengalami proses perkembangan. Ciri larva yang tidak terinfeksi ditandai dengan tubuh larva berwarna kuning serta tidak mengeluarkan bau busuk. Perlakuan volume starter bakteri $S$. marcescens terhadap larva $B$. longissima menunjukkan adanya aktivitas mortalitas bakteri dari volume perlakuan B $(5 \mathrm{ml}), \mathrm{C}(7,5 \mathrm{ml}), \mathrm{D}(10 \mathrm{ml}), \mathrm{E}(12,5 \mathrm{ml})$, dan F $(15 \mathrm{ml})$. Aktivitas mortalitas larva dari masing-masing perlakuan terlihat pada 12 jsa dan nilai mortalitas semakin bertambah hingga pengamatan 72 jsa.

Mortalitas larva ditandai dengan perubahan warna tubuh menjadi merah muda di bagian cercus larva dan hitam dibagian cepal (Gambar 1 a), bagian tubuh larva lainnya berwarna hitam dan berbau busuk (Gambar 1 b, c). Bagian tubuh larva terlihat mengalami perubahan warna menjadi merah muda kemudian menjadi warna hitam dan menyebar ke seluruh tubuh larva. Pigmen merah muda yang muncul pada tubuh larva diduga senyawa prodigiosin,metabolit sekunder dari $S$. marcescens. Bidari et al. (2017) Prodigiosin yang dihasilkan oleh $S$. marcescensmemiliki senyawa larvasida. Wicaksono dkk (2014)menyatakan bahwaprodigiosin mulai disintetis saat bakteri memasuki fase eksponensial, yang bersifat antibakteri dan antifungal.
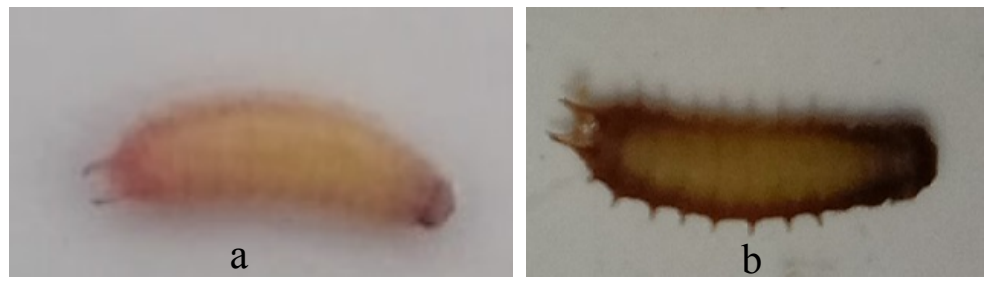

Gambar 1.Ciri-ciriPatogenitasS.marcescens: a) tubuh larva kemerahan, b) pinggirantubuh larva menghitam, c) seluruhtubuh larva hitam (Data Primer, 2019).

Hasil penelitian menunjukkan larva lebih banyak berwarna hitam dibandingkan berpigmen merah muda. Perubahan warna hitam diduga disebabkan pecahnya sel-sel larva akibat nekrosis atau pembengkakkan pada membran plasma sel larva. Pendapat ini didukung oleh Jumiarti (2012) melaporkan bahwa larva yang mengalami mortalitas setelah diaplikasi dengan $S$. marcescens juga ditandai dengan adanya perubahan warna menjadi hitam. Pendapat ini didukung oleh Salaki (2011) bahwa gejala umum yang timbul saat larva terinfeksi bakteri yakni, gerakan melambat, terjadi perubahan warna tubuh serta adanya cairan yang berbau busuk.

Tabe1 3.2.Hasil Analisis Uji Duncan padasetiapPerlakuan

\begin{tabular}{|c|c|c|}
\hline Volume Starter & Persen Mortalitas (\%) & Notasi \\
\hline Perlakuan A (Kontrol) & 0 & $\mathrm{~A}$ \\
\hline Perlakuan B (5 ml) & 40 & $\mathrm{~B}$ \\
\hline Perlakuan C (7,5 ml) & 50 & $\mathrm{Bc}$ \\
\hline Perlakuan D (10 ml) & 62,5 & $\mathrm{Cd}$ \\
\hline Perlakuan E (12,5 ml) & 77,5 & De \\
\hline Perlakuan F (15 ml) & 92,5 & $\mathrm{E}$ \\
\hline
\end{tabular}

Keterangan: Notasi huruf yang berbeda menunjukkan terdapat perbedaan signifikan dengan nilai $\alpha$ $=0,05$.

Mortalitas larva $B$. longissima dapat dipengaruhi dari dua faktor utama, yaitu jumlah sel $S$. marcescens dari setiap perlakuan, dan lama waktu aplikasi. Hal ini ditunjukan dengan hasil analisis Duncan dan analisis Probit $\mathrm{LT}_{50}$. Hasil analisis Duncan (Tabel 2) didapatkan perbedaan signifikan antara perlakuan 
A (kontrol), E (12,5 ml), dan F $(15 \mathrm{ml})$. Data tersebut menunjukkan perlakuan volume $S$. marcescens mempengaruhi mortalitas larva, perlakuan E $(12,5 \mathrm{ml})$ dapat membunuh larva sebanyak $92,5 \%$ pada waktu $72 \mathrm{jam}$. Hasil analisis probit $\mathrm{LT}_{50}$ didapatkan nilai $\mathrm{R}^{2}$ rata-rata pada semua perlakuan 0,87 , hal ini membuktikan sebanyak $87 \%$ mortalitas larva dipengaruhi oleh lama waktu pengamatan. Pendapat ini didukung oleh Tinuki (2010) bahwa regresi probit digunakan untuk menggambarkan suatu hubungan antara respon (Y) dan prediktor (X).

\subsection{Analisis Probit Lethal Time (LT) $50 \%$ Larva B. longissima pada setiap Perlakuan Selama Pengamatan}

Nilai $\mathrm{LT}_{50}$ didapatkan dari hasil analisis probit pada setiap perlakuan. Analisis probit bertujuan untuk melihat pada jam atau waktu berapa volume starter pada masing-masing perlakuan dapat mematikan larva sebanyak $50 \%$. Nilai probit $\mathrm{LT}_{50}$ didapatkan dari transformasi persen mortalitas ke unit probit kemudian diregresikan dengan transformasi $\log \mathrm{t}$ (waktu) sehingga didapatkan garis persamaan linier. Rata-rata nilai $R$ square $\left(\mathrm{R}^{2}\right)$ dari semua perlakuan yakni 0,87 (Tabel 2). Hal ini membuktikan bahwa transformasi log t pada setiap perlakuan berpengaruh terhadap nilai probit. Hasil analisis probit nilai $\mathrm{LT}_{50}$ pada setiap perlakuan dapat dilihat pada Gambar 4.1.

Tabel 3.2. Nilai $R$ Squarepadamasing-masingperlakuan

\begin{tabular}{cc}
\hline Perlakuan & Nilai R Square \\
\hline B $(5 \mathrm{ml})$ & 0.86 \\
C $(7,5 \mathrm{ml})$ & 0.86 \\
D $(10 \mathrm{ml})$ & 0.85 \\
E $(12,5 \mathrm{ml})$ & 0.87 \\
F $(15 \mathrm{ml})$ & 0.88 \\
\hline
\end{tabular}

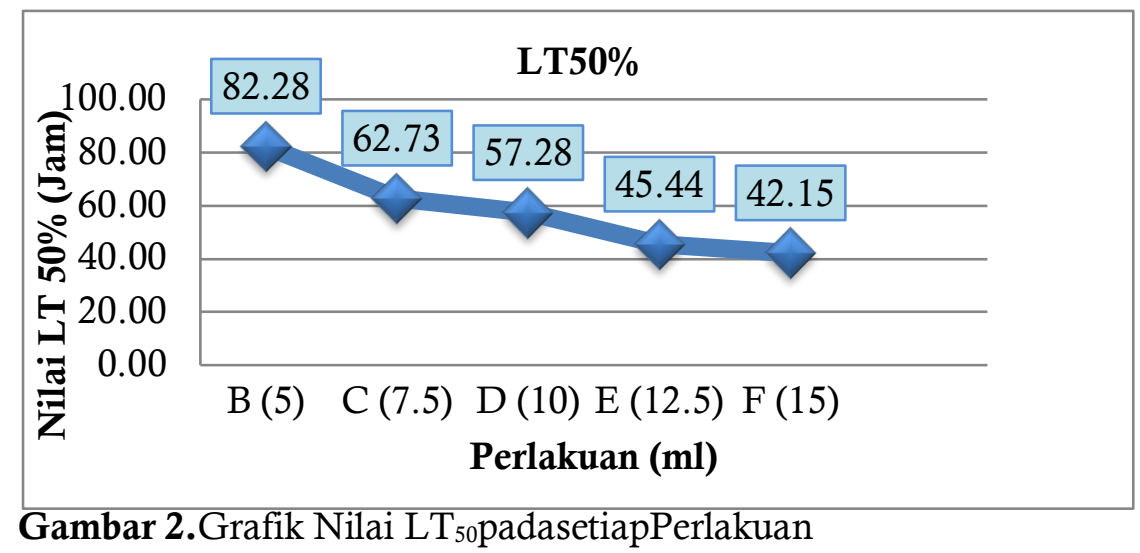

Hasil yang didapatkan adalah kontrol pada perlakuan tidak menunjukkan aktivitas mortalitas sehingga nilai $\mathrm{LT}_{50}$ yang didapatkan adalah 0 , disebabkan nilai persamaan $\mathrm{x}$ dan $\mathrm{y}=0$. Perlakuan $\mathrm{B}(5$ ml) memiliki nilai $\mathrm{LT}_{50}$ tertinggi dibandingkan dengan perlakuan lainya yakni 82,28 jam sedangkan nilai $\mathrm{LT}_{50}$ terendah yakni pada perlakuan $\mathrm{F}(15 \mathrm{ml}) 42,15 \mathrm{jam}$. Sehingga dapat disimpulkan yang paling efektif terhadap mortalitas larva B. longissima yakni perlakuan $\mathrm{F}(15 \mathrm{ml})$ pada waktu 42,15 jam dapat membunuh larva sebanyak $50 \%$.

Hasil penelitian ini menunjukkan semakin tinggi perlakuan volume starter bakteri $S$. marcescens maka nilai persen mortalitas semakin tinggi dan nilai $\mathrm{LT}_{50}$ yang didapatkan semakin rendah. Hal ini diduga dipengaruhi oleh jumlah sel bakteri yang diaplikasi pada larva $B$. longissima. Menurut Tampubolon dkk (2013) jumlah sel bakteri entomopatogen akan mempengaruhi tingkat mortalitas larva. Penelitian ini menunjukkan semakin banyak sel bakteri maka tingkat mortalitas semakin tinggi.

Bakteri $S$. marcescens dikenal dengan bakteri yang dapat menginfeksi serangga. Senyawa sekunder dan beberapa enzim hidrolitik yang dihasilkan oleh bakteri ini menjadikan bakteri ini patogen terhadap serangga. Keberadaan berbagai jenis ini diduga sebagai penyebab kematian larva. Menurut Ishi et al. 
(2014) Bakteri S. marcescens dapat mensekresikan senyawa sekunder seperti prodigiosin dan Serralysin. Sekresi enzim hidrolitik lainnya oleh bakteri $S$. marcescens yakni menurut Bidari et al. (2014) kitinase, protease dan karbohidrase. Jumiarti (2012) juga menyatakan enzim hidrolitik yang dihasilkan oleh $S$. marcescens adalah nuklease.

Larva yang akan mengalami mortal mulanya mengalami paralisis. Hasil pengamatan menunjukkan larva mengalami aktivitas bergerak kurang namun masih terindikasi hidup yang ditandai dengan bagian oral larva masih bergerak sedangkan bagian lainnya tidak. Paralisis ini di duga karena adanya aktivitas dari enzim nuklease. Enzim Nuklease yang disekresikan oleh $S$. marcescens diduga jenis Deoxyribonuclease (DNAse) dapat memecah ikatan rantai polinukleotida pada DNAmenjadi mononukleotida sehingga menyebabkan proses perkembangan larva terganggu. Nestle \& Roberts (1969) menjelaskan proses pemecahan DNA menjadi 5- monolukleotida terjadi apabila Deoxyribonuclease berikatan dengan $\mathrm{Mg}^{2+}$ dan $\mathrm{Ca}^{2+}$. Hal ini disebabkan DNAse membutuhkan kofaktor sehingga harus berikatan dahulu dengan $\mathrm{Mg}^{2+}$ dan $\mathrm{Ca}^{2+}$ agar enzim ini aktif. Muliawan (2007) juga melaporkan bahwa Deoxyribonuclease (DNAse) berperan membantu bakteri dalam melakukan penetrasi ke jaringan inang yang menyebabkan aktivitas sel-sel terganggu.

Enzim kitinase merupakan enzim yang dapat mendegradasi senyawa kitin pada bakteri, sehingga dalam penelitian ini terlihat bagian cercus di bagian tubuh larva menjadi warna merah muda, Gambar 1 a. Pratiwi dkk (2015) berpendapat bahwa enzim kitinase bekerja dengan melisis kulit larva dengan mengubah senyawa kitin menjadi N-asetilglukosamin. Senyawa N-asetilglukosamin hasil dari degradasi kitin kemudian dimanfaatkan oleh bakteri sebagai sumber karbon dalam pemenuhan nutrisi. Hal ini menyebabkan tubuh larva mengalami kerusakkan akibat pemanfaatan karbon oleh bakteri.

Enzim hidrolitik lainnya yang mempengaruhi kematian larva yakni enzim protease. Menurut Bhargavi \& Prakasham (2012) protease adalah enzim hidrolitik yang aktif pada sistem pencernaan larva yang mengubah protein gologan peptida menjadi asam amino. Hasil penelitian Bhargavi \& Prakasham (2012) melaporkan bahwa jenis protease yang disekresikan oleh bakteri Serratia adalah serralysin. Ishi et al. (2014) menjelaskan bahwa sekresi serralysin oleh $S$. marcescens dapat menekan imunitas seluler dengan menurunkan sifat adesif sel immuno surveillance. Lebih lanjut Tambupulon dkk (2013) menyatakan bahwa kristal protein bakteri yang masuk ke dalam tubuh akan menempel di usus larva, protein yang aktif akan diterima oleh reseptor protein di usus sehingga memicu terjadinya respon seluler seperti berhentinya proses metabolisme sel.

Enzim hidrolitik lainnya yang disekresikan oleh bakteri $S$. marcescens adalah karbohidrase. $S$. marcescens mensekresikan enzim karbohidrase untuk mendegradasi karbohidrat menjadi senyawa yang lebih sederhana guna untuk memenuhi kebutuhan nutrisi. Seperti yang telah dilaporkan oleh Wicaksono, dkk (2017) bahwa pada masa pertumbuhan S. marcescens akan mensekresikan enzim karbohidrase jenis maltase dan laktase. Kedua jenis enzim ini akan digunakan bakteri dalam memecah maltosa menjadi glukosa serta laktosa menjadi glukosa dan galaktosa.

Kerusakan yang terjadi secara anatomi pada larva $B$. longissima setelah diaplikasi dengan bakteri entomopatogen jenis Serratia marcecscens belum diketahui lebih jelas. Hasil penelitian yang didapatkan hanya lebih memfokuskan mortalitas larva dan perubahan secara morfologi dengan variabel $\mathrm{X}$ volume starter bakteri. Hasil yang didapatkan keberadaan enzim hidrolitik dan senyawa sekunder memberikan alasan penting terkait perubahan morfologi dari segi warna dan mortalitas larva $B$. longissima. Patogenitas bakteri terhadap larva juga dipengaruhi oleh faktor lingkungan, namun dalam penelitian ini tidak dijadikan sebagai objek utama melainkan hanya sebagai data pendukung penelitian.

Faktor lingkungan suhu dan kelembaban merupakan salah satu faktor pendukung keberhasilan patogenitas bakteri, karena suhu mempengaruhi aktivitas kerja enzim yang dihasilkan oleh $S$. marcescens dalam mendegradasi sel inang. Suhu yang tinggi dapat merusak enzim sedangkan suhu yang terlalu rendah menyebabkan enzim menjadi inaktif. Pendapat ini sesuai dengan Priyatno dkk (2011) menyatakan bahwa suhu $35^{\circ} \mathrm{C}$ merupakan suhu optimum genus $S$. marcescens untuk mensekresikan senyawa sekunder berupa prodigiosin. Pratiwi dkk (2015) juga menjelaskan suhu optimum yang dibutuhkan untuk kerja enzim hidrolitk adalah $30-40^{\circ} \mathrm{C}$. Suhu yang rendah $<10^{\circ} \mathrm{C}$ dapat memicu inaktivasi enzim sedangkan suhu yang semakin tinggi $>40^{\circ} \mathrm{C}$ menyebabkan enzim terdegradasi dengan sendirinya.

Pengukuran faktor lingkungan menunjukkan rata-rata nilai suhu dan kelembaban udara di laboratorium Biokimia mendukung pertumbuhan dan perkembangan larva $B$. longissima dan bakteri $S$. marcescens. Hal ini disebabkan nilai rata-rata suhu dan kelembaban rata-rata setiap hari mencapai 28$31^{\circ} \mathrm{C}$ dan $81-84 \%$.Giang \& Nakamura (2009) menjelaskan suhu dan kelembaban optimum dan 
maksimum untuk keberlangsungan hidup $B$. longissima adalah $25-30^{\circ} \mathrm{C}$ dan $45^{\circ} \mathrm{C}$ sedangkan kelembaban yakni $<95 \%$. Suhu optimum dan maksimum yang mendukung keberlangsungan hidup $S$. marcescensmenurut Pratiwi dkk(2015) yakni $30^{\circ} \mathrm{C}$ dan maksimum $40^{\circ} \mathrm{C}$.

Hasil penelitian menunjukkan banyaknya volume $S$. marcescens mempengaruhi nilai mortalitas larva. Berdasarkan analisis probit $\mathrm{LT}_{50}$ menunjukkan bahwa volume starter tertinggi $\mathrm{F} 15 \mathrm{ml}$ memiliki nilai $\mathrm{LT}_{50}$ lebih rendah yakni 42,15 jam dibandingkan dengan perlakuan lainnya. Indikator yang mempengaruhi terjadinya mortalitas larva yakni kerapatan bakteri, hal ini disebabkan kerapatan bakteri sangat berpengaruh terhadap akumulasi produksi enzim hidrolitik yang dapat menyebabkan kematian pada larva.

\section{Kesimpulan}

Aktivitas entomopatogen $S$. marcescens berpengaruh terhadap mortalitas larva kumbang kelapa ( $B$. longissima) dengan nilai $\mathrm{F}$ hitung 73,584 dan waktu yang dibutuhkan untuk mencapai $\mathrm{LT}_{50}$. Perlakuan volume starter $\mathrm{F}(15 \mathrm{ml})$ mampu membunuh larva dengan $\mathrm{LT}_{50} 42,15$ jam.

\section{Ucapan Terima Kasih}

Ucapan terimakasih penulis sampaikan kepada Bpk Prof. Dr. Ir. Meldy L.A. Hosang, M.Si dan Ibu Dra. Novalisa T.E. Lumentut, SP, M.Sc yang telah memberikan ide penelitian sekaligus membimbing penulis dalam melakukan pralaboratorium di Balai Penelitian dan Pengembangan Tanaman Palma, Manado (Balit Palma).

\section{Referensi}

Bhargavi, P, L. \&RS.Prakasham,. 2012. Proteolytic Enzyme Production by Isolated Serratia sp. RSPB11: Role of Environmental Parameters. Current Trends in Biotechnology and Pharmacy. 6(1): 5565

Bidari, F., M. Shams-Bakhsh\& M.Mehrabadi. 2018. Isolation and Characterization of a S. marcescens with Insecticidal Activity from Polyphylla olivieri (Col.: Scarabaeidae). Journal of Applied Entomology. 142(2): 162-172.

Giang, H. T.\&S. Nakamura. 2009. The Study on Biological Characteristics of Brontispa longissima (Gestro) (Coleoptera: Chrysomelidae). J. Sci. Dev. 7(2): 159-164.

Herdatiarni, F., T. Himawan\& Rachmawaty, R. 2014. Eksplorasi Cendawan Entomopatogen Beauveria sp. Menggunakan Serangga Umpan pada Komoditas Jagung, Tomat dan Wortel Organik di Batu, Malang. Jurnal HPT. 1(3): 1-11

Hidayat, N., MC.Padaga\& S. Suhartini. 2006. Mikrobiologi Industri. Edisi 1. Andi Offest. Yogyakarta.

Ishi, K., Tatsuo, A., H. Hiroshi\& S. Kazuhisa. 2014. S. marcescens Suppresses Host Cellular Immunity via the Production of an Adhesion-Inhibitory Factor against Immunosurveillance Cells. The Journal of Biological Chemistry. 289(9):5876-5888.

Jumiarti, P. 2012. Pemurnian dan Karakterisasi Protein Insektisidal dari Bakteri Entomopatogen Serratia marcescens. [Skripsi]. Bogor: Institut Pertanian Bogor.

Lumentut, N. \&Indrawanto, C. 2013. Biologi Brontispa longissima Varitas Frogatti, Selebensis dan Javana pada Kelapa Dalam Mapanget dan Kelapa Genjah Raja. B. Palma. 14(2): 76-81.

Lumentut, N., S. Karinda., L. Sulistyowati\&RD.Puspitarini. 2013. The Demographic of Brontispa longissima variety of Celebensis Gestro (Coleoptera: Chrysomelidae) on Mapanget Tall Coconut and Brown Dwarf Coconut. IOSR Journal of Agriculture and Veterinary Science (IOSR-JAVS). 6(2): 33-37. 
Muliawan, S. 2007. Bakteri Anaerob yang Erat Kaitannya dengan Problem di Klinik: Diagnosis dan Penatalaksanaan. Edisi 1. Buku Kedokteran EGC.Jakara.

Nestle, M. \& WK. Roberts. 1969. An Extracellular Nuclease from Serratia marcescens. The Journal of Biological Chemistry. 244(19): 5219-5225.

Pratiwi, R, S.,TE. Susanto\& YAK. Wardani. 2015. Enzim Kitinase dan Aplikasi di Bidang Industri: Kajian Pustaka. Jurnal Pangan dan Agroindustri. 3(3): 878-887.

Priyatno, TP., YA. Dahliani., Y. Suryadi., IM. Samudra., DN. Susilowati., I. Rusmana\& C. Irwan. 2011. Identifikasi Entomopatogen Bakteri Merah Pada Wereng Batang Coklat (Nilaparvata lugens Stål.). Jurnal Agrobiogen. 7(2): 85-95

Purkayastha, GD., P. Mangar., A. Saha\&D. Saha. 2018.Evaluation of the Biocontrol Efficacy of a $S$. marcescens Strain Indigenous to Tea Rhizosphere for the Management of Root Rot Disease in Tea. Plos One.13(2):1-27.

Rini, M. S., R. Rahardian., M. Hadi\&D. Zulfiana. 2016. Uji Efikasi Beberapa Isolat Bakteri Entomopatogen terhadap Kecoak (Orthoptera) Periplaneta americana (L.) dan Blatella germanica (L.) dalam Skala Laboratorium. Jurnal Biologi. 5(2): 1-10.

Salaki, CL. 2011. Eksplorasi Bakteri Entomopatogenik Pengendali Hama Plutella xylostelladanSpodoptera sp. PadaTanamanKubisBungadanBrokoli.Eugenia. 17(3): 209-219.

Tampubolon, DY., Y. Pangestiningsih., F. Zahara\& F. Manik. Uji Patogenitas Bacillus thuringiensis dan Metarhizium anisopliae terhadap Mortalitas Spodoptera litura Fabr (Lepidoptera: Noctuidae) di Laboratorium. Jurnal Online Agroteknologi. 1(3):783-793.

Yus, ID., BT. Rahardjo\& T. Himawan. 2014. Pengaruh Aplikasi Pseudomonas fluorescen dan Bacillus subtilis terhadapMortalitas Nematoda Puru Akar (Meloidogyne javanica) di Laboratorium. Jurnal HPT. 2(3): 9-17.

Wicaksono, S., E. Kusdiyantini\& Raharjo, B. 2017. Pertumbuhan dan Produksi Pigmen Merah oleh $S$. marcescens pada Berbagai Sumber Karbon. Jurnal Biologi. 6(3): 66-75.

Widariyanto, R., MI.Pinem\& F. Zahara. 2017. Patogenitas Beberapa Cendawan Entomopatogen(Lecanicillium lecanii, Metarhizium anisopliae, danBeauveria bassiana) terhadap Aphis glycinespadaTanaman Kedelai. Jurnal Agroekoteknologi FP USU. 5(2): 8- 16 